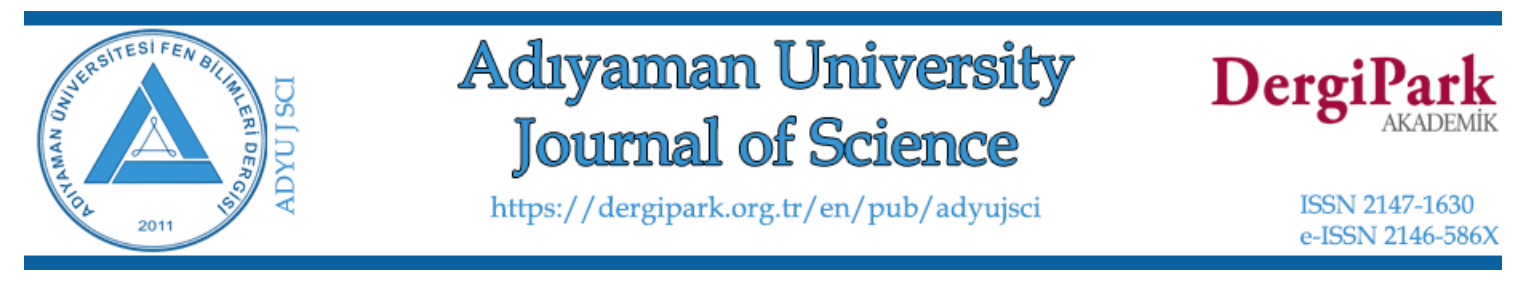

\title{
Comparatively Investigation of Textile Dye Decolorization by a White Rot Fungus and Various Bacterial Strains
}

\footnotetext{
Emre BİRHANLI ${ }^{1, *}$, Özfer YEŞILAADA ${ }^{1}$, Ahmet ÇABUK ${ }^{2}$, Filiz BORAN ${ }^{1}$, Eray TATLICI ${ }^{1}$

${ }^{1}$ Inonu University, Arts and Science Faculty, Department of Biology, Malatya, Turkey. emre.birhanli@inonu.edu.tr,ORCID ID:0000-0001-7965-4979; ozfer.yesilada@inonu.edu.tr,ORCID ID: 0000-0003-0038-6575; filiz.kuru@inonu.edu.tr, ORCID ID: 0000-0002-8801-7987; eraytatlici@gmail.com,ORCIDID:0000-0003-2589-4234

${ }^{2}$ Eskisehir Osmangazi University, Arts and Science Faculty, Department of Biology, Eskisehir, Turkey acabuk@ogu.edu.tr, ORCID ID: 0000-0002-4619-6948
}

$\begin{array}{lll}\text { Received: } 19.07 .2021 & \text { Accepted: 19.10.2021 } & \text { Published: } 31.12 .2021\end{array}$

\section{Abstract}

The aim of this study is to comparatively investigate the decolorization of Reactive Blue 171 (RB 171) by using three different bacterial strains as Bacillus megaterium A1 (A1), Gordonia sp. MC-D1 (D1), and Bacillus pumilus D3 (D3) and also a white rot fungus (Pleurotus ostreatus). All tested bacteria were incubated with RB 171 dye at $150 \mathrm{mg} / \mathrm{L}$ concentration for $24-72 \mathrm{~h}$ under static or agitated $(150 \mathrm{rpm})$ conditions while the fungus was incubated with $150 \mathrm{mg} / \mathrm{L}$ of the dye under the same conditions for 3-24 h. The highest bacterial decolorization values were obtained after $72 \mathrm{~h}$ of incubation under static conditions, and the maximum decolorization rates were detected as 84,83 and $75 \%$ for $\mathrm{A} 1, \mathrm{D} 1$, and D3, respectively. However, the color of RB 171 dye was removed at 93\% rate by Pleurotus ostreatus under static conditions after $24 \mathrm{~h}$ of incubation. Similar results were also obtained from the agitated studies of the tested fungal and bacterial strains except A1. The maximum 
decolorization values obtained with A1, D1, and D3 at $150 \mathrm{rpm}, 72 \mathrm{~h}$ were 30,88 and $89 \%$, respectively. The highest decolorization activities of Pleurotus ostreatus were $93 \%$ for both static and agitated $(150 \mathrm{rpm})$ conditions. In addition, zymogram analyzes of the fungal culture fluids obtained from SBM, and SBM containing $150 \mathrm{mg} / \mathrm{L} \mathrm{RB} 171$ were also performed to detect the presence of laccase.

Keywords: Bacterium; Decolorization; Textile dye; White rot fungus; Zymogram.

\section{Bir Beyaz Çürükçül Fungus ve Çeşitli Bakteriyel Suşlar ile Tekstil Boyasının Renginin Gideriminin Karşılaştırmalı Olarak Araştırılması \\ Öz}

Bu çalışmanın amacı, üç farklı bakteriyel suş Bacillus megaterium A1 (A1), Gordonia sp. MC-D1 (D1) and Bacillus pumilus D3 (D3) ve ayrıca bir beyaz çürükçül fungusun (Pleurotus ostreatus) kullanımı ile Reaktif Mavi 171' in (RM 171) renginin gideriminin karşılaştırmalı olarak araştırılmasıdır. Test edilen tüm bakteriler $150 \mathrm{mg} / \mathrm{L}$ konsantrasyonda RM 171 boyası ile 24-72 saat boyunca statik ve çalkalamalı $(150 \mathrm{rpm})$ koşullarda inkübe edilirken fungus 150 mg/L boya ile aynı koşullarda 3-24 saat boyunca inkübe edildi. En yüksek bakteriyel renk giderimleri statik koşullarda 72 saat inkübasyon sonrasında elde edildi ve maksimum renk giderim oranları A1, D1 ve D3 için sırasıyla 84,83 ve \%75 olarak saptandı. Bununla birlikte, Pleurotus ostreatus ile statik koşullarda, 24 saat inkübasyon sonrası RM 171 boyasının rengi \%93 oranında giderildi. Benzer sonuçlar A1 hariç test edilen fungal ve bakteriyel suşların çalkalamalı çalışmalarından da elde edildi. A1, D1 ve D3 ile $150 \mathrm{rpm}$ ve 72 saatte elde edilen maksimum renk giderim değerleri sirasıyla 30,88 ve $\% 89^{\prime}$ dur. Pleurotus ostreatus' un en yüksek renk giderim aktiviteleri hem statik hem de çalkalamalı (150 rpm) koşullarda \%93 idi. Ayrıca lakkaz varlığının tespiti amacıyla SBM ve 150 mg/L RB 171 içeren SBM'den elde edilen fungal kültür sıvılarının zimogram analizleri de yapıldı.

Anahtar Kelimeler: Bakteri; Renk giderimi; Tekstil boyası; Beyaz çürükçül fungus; Zimogram.

\section{Introduction}

Textile and dye industry wastewaters contain various textile dyes. Among these dyes; Reactive dyes are widely used in the textile industry due to their high binding capacities to cellulosic fibers. Therefore, reactive dyes are used at much higher rates than conventional dyes, and consequently there are more reactive dyes residues in textile factory wastewaters [1]. These wastewaters can be discharged to aquatic environments or soil without any or sufficient 
treatment and negatively affect the aquatic life by reducing photosynthesis and also oxygen level in the water because of their intense color $[2,3]$. However, the toxic and/or genotoxic effects of the dyes found in these wastewaters can adversely affect aquatic and terrestrial ecosystems, leading to serious environmental problems [4, 5]. For this reason, these wastewaters must be subjected to treatment process before being discharged to the environment. Because many synthetic dyes have antimicrobial effects, the textile dyes are generally resistant to biodegradation by the conventional biological wastewater treatment systems. Accordingly, studies on the color removal of textile wastewaters were generally carried out using physicochemical methods such as adsorption, precipitation, filtration, electrochemical oxidation in the literature [6]. But high amounts of sludge formation and insufficient degradation of dyes and removal of their degradation products are the disadvantages of physicochemical processes. However, their economic unfeasibility and environmental pollutant potential of the chemicals used are the other negative aspects of physicochemical processes [7-9]. In addition, the yield of color removal in traditional biological wastewater treatment methods is low. Thus, environmentally friendly and effective methods are needed for color removal of these dyes. In accordance with this purpose, many researchers are trying to find ecofriendly and efficient biological alternatives for dye decolorization [3, 10, 11]. Microbial decolorization may be an alternative method for color removal of these dyes, by selecting the appropriate methods and microorganisms. Bacteria and also white rot fungus can decolorize and detoxify of textile dyes $[12,13]$. Laccases (E.C. 1.10.3.2) are produced by most of white rot fungi, and these enzmes are generally secreted extracellularly [14]. There are various reports in the literature that fungal laccases are responsible for the decolorization of many dyes $[12,13,15,16]$. Accordingly, the spectrophotometric and zymogram analyzes were performed to detect if the laccase was the enzyme responsible from fungal dye decolorization. The aim of the study is to compare the decolorization potentials of Reactive Blue 171 (RB 171) dye by using the isolated bacteria like Bacillus megaterium A1, Gordonia sp. MC-D1, Bacillus pumilus D3, and a white rot fungus (Pleurotus ostreatus) in various conditions.

\section{Materials and Methods}

\subsection{Microorganisms}

In this study, three isolated bacteria and one white rot fungus were used for decolorization of Reactive Blue 171 (RB 171). Bacteria used in the studies were Bacillus megaterium strain A1 (A1, Accession number KC579390), Gordonia sp. MC-D1 (D1, Accession number KF663602), Bacillus pumilus D3 (D3, Accession number JX860616) while the fungus was Pleurotus ostreatus (P. ostreatus). Bacteria were transferred to fresh Nutrient Agar (NA) plates every 
month and produced as pure solid culture at $30{ }^{\circ} \mathrm{C}$. Similarly, the fungus was transferred to the plates containing fresh Sabouraud Dextrose Agar (SDA) every month and produced as pure filamentous fungal culture at $30^{\circ} \mathrm{C}$. The obtained pure bacteria and fungus cultures are kept in stock at $4{ }^{\circ} \mathrm{C}$ in a refrigerator of Inonu University Arts and Science Faculty Biology Department.

\subsection{Textile dye}

RB 171 (Fig. 1), an azo dye, was used as a textile dye in the studies. This dye was added to Nutrient Broth (NB) and Stock Basal Medium (SBM) at final concentration as $150 \mathrm{mg} / \mathrm{L}$.<smiles>CS(=O)(=O)c1cccc(Nc2nc(Cl)nc(Nc3ccc(S(N)(=O)=O)c(N)c3N=Nc3c(S(=O)(=O)O)cc4cc(N=Nc5cc(Nc6nc(Cl)nc(Nc7cccc(S(N)(=O)=O)c7)n6)ccc5S(N)(=O)=O)c(N)c(N)c4c3O)n2)c1</smiles>

Figure 1: The chemical structure of RB 171 dye

\subsection{Preparation of bacterial cultures}

The samples taken from the stock solid cultures of A1, D1 and D3 produced on NA were transferred to NB media. Then these bacteria were incubated at $30^{\circ} \mathrm{C}$ at $150 \mathrm{rpm}$ for obtaining the liquid bacterial cultures to be used in the experiments.

\subsection{Preparation of fungal cultures}

The mycelia of $P$. ostreatus were incubated at $30{ }^{\circ} \mathrm{C}$ on slant Sabouraud Dextrose Agar (SDA) for 7 days. Then the mycelial suspensions were utilized for inoculum [17]. The fungus was precultured in $250 \mathrm{~mL}$ flasks containing $100 \mathrm{~mL}$ Sabouraud Dextrose Broth (SDB) at 150 rpm for 5 days and then homogenized at low speed under aseptic conditions. The homogenized mycelia were utilized as the inocula [18].

\subsection{Dye decolorization studies}

After preliminary preparations, $1 \mathrm{~mL}$ of $\mathrm{A} 1, \mathrm{D} 1$ and $\mathrm{D} 3$ liquid cultures were separately transferred to NB media containing $150 \mathrm{mg} / \mathrm{L} \mathrm{RB} 171$ at the final concentration. However, $2.5 \mathrm{~mL}$ of homogenized $P$. ostreatus mycelia were transferred into SBM containing $150 \mathrm{mg} / \mathrm{L}$ 
RB 171 dye. SBM consisted of (g/L): $\mathrm{KH}_{2} \mathrm{PO}_{4} 0.2 ; \mathrm{CaCl}_{2} \cdot 2 \mathrm{H}_{2} \mathrm{O} 0.1 ; \mathrm{MgSO}_{4} \cdot 7 \mathrm{H}_{2} \mathrm{O} 0.05$; $\mathrm{NH}_{4} \mathrm{H}_{2} \mathrm{PO}_{4} 0.5 ; \mathrm{FeSO}_{4} \cdot 7 \mathrm{H}_{2} \mathrm{O} 0.035$; glucose 2 ; yeast extract 1 . The samples were incubated at $30{ }^{\circ} \mathrm{C}$ under static and agitated (150 rpm) conditions.

Dye decolorization activities of microorganisms were determined by spectrophotometric (Shimadzu-UV-1601, UV/Visible) measurements at 24, 48 and 72th hours for the bacterial strains. However, the decolorization rates obtained with use of the fungus were detected at 3,6, 9, 12, and 24th hours. The maximum wavelength of the RB 171 was determined as $619 \mathrm{~nm}$ via spectrophotometric scanning. The percents of dye decolorization activities obtained after the treatment of RB 171 dye with the microorganisms as stated above were calculated against the control groups at $619 \mathrm{~nm}$. All experiments were performed at least 3 replicates.

\subsection{Spectrophotometric analyzes of fungal laccase}

The crude laccase activities of Pleurotus ostreatus culture fluids from SBM and $\mathrm{SBM}+150 \mathrm{mg} / \mathrm{L}$ RB 171 were detected by spectrophotometrically at $420 \mathrm{~nm}$ using ABTS [2,2Azino-bis (3-ethylbenzthiazoline-6- sulfonic acid)] as the substrate [19].

\subsection{Zymogram analysis of Pleurotus ostreatus culture fluids}

Pleurotus ostreatus culture fluids obtained from two different media (SBM and SBM containing $150 \mathrm{mg} / \mathrm{L} \mathrm{RB} \mathrm{171)}$ were used as the crude laccase enzyme sources. Native polyacrylamide gel electrophoresis (Native PAGE) were performed on native polyacrylamide gels. Laccase activities were determined on native polyacrylamide gels with ABTS as the substrate [12].

\section{Results and Discussion}

\subsection{Bacterial dye decolorization}

Among the tested bacterial species, D1 and D3 performed better color removals at agitated condition while A1 effectively decolorized RB 171 dye at static condition. This color removal clearly seen at Fig. 2 as macroscobically, and this experiment was also supported by spectrophotometric scanning (Fig. 3). 


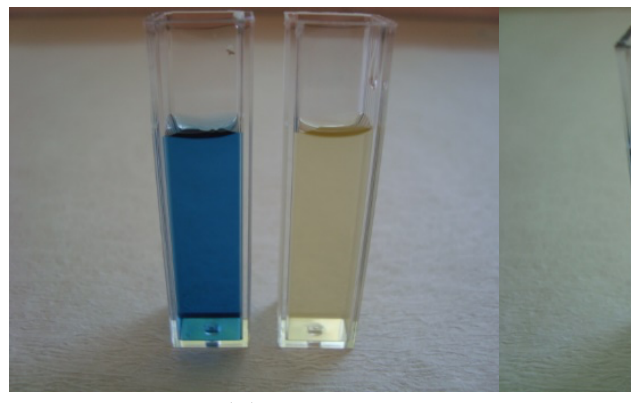

(a)

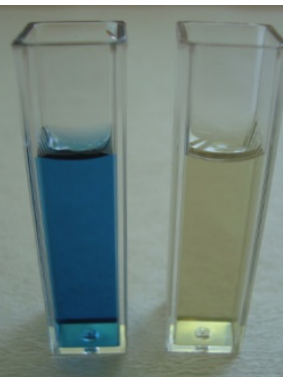

(b)

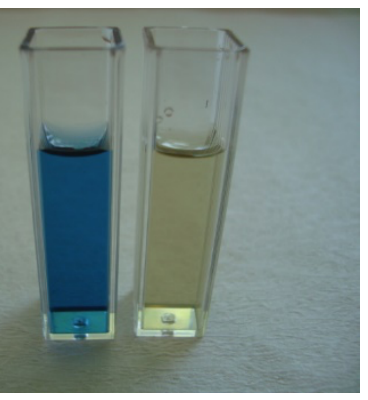

(c)

Figure 2: Macroscopic images of the decolorization of RB 171 under static condition by A1 (a) and under agitated condition by D1 (b) and D3 (c)

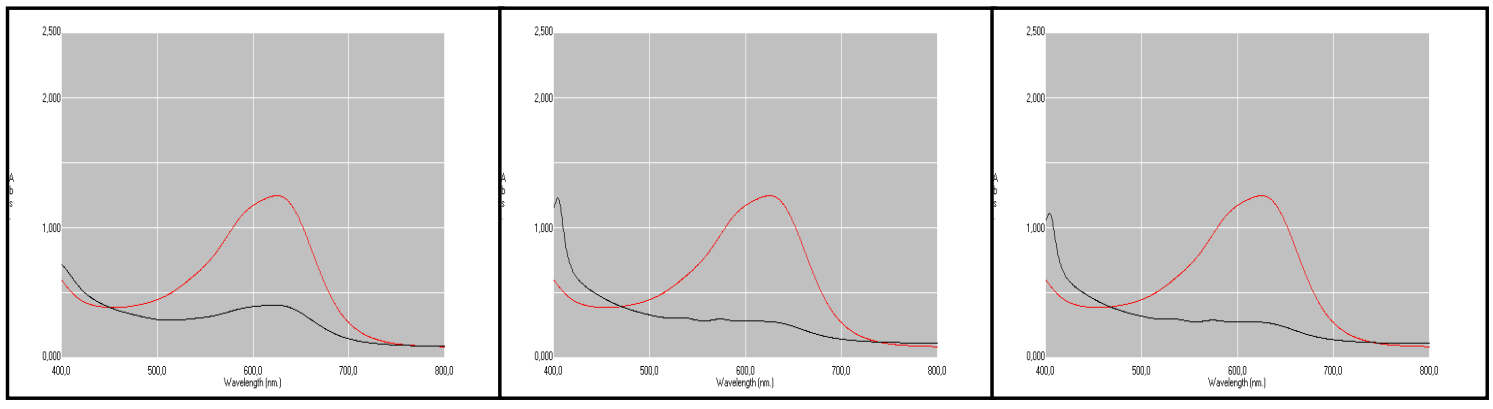

(a)

(c)

Figure 3: Spectrophotometric scanning images of the decolorization of RB 171 under static condition by A1 (a) and under agitated condition by D1 (b) and D3 (c)

The color removal percentages based on the time dependent absorbance measurements could be seen at Table 1 . The highest color removal was generally obtained at 72 th hour for all of the bacterial strains tested in both static and agitated conditions (Table 1). The most effective color removals were detected as 84,83 , and $75 \%$ in static conditions while the maximum decolorization rates were 30,88 , and $89 \%$ in agitated conditions for the strains of A1, D1, and D3, respectively.

Bacterial decolorization efficiency may vary depending on the type of bacteria tested, the dye, and whether the incubation conditions are static or agitated. For this purpose, different bacterial species and incubation conditions have been tested in decolorization of various dyes in many studies. Accordingly; in some of the studies in the literature, it is reported that higher decolorization rates were obtained in static conditions [20-22] and in others under shaking conditions [23-25]. This situation can be explained by the metabolic diversity of the tested bacterial species.

Six different isolates (DEC1-DEC6) of Aeromonas hydrophila were tested for decolorization of RB 171 dye at $100 \mathrm{mg} / \mathrm{mL}$ concentration in a work by Chen et al. [26]. It was stated that the highest decolorization activity was $80 \%$ for DEC 1 , and DEC 6 isolates at the 7 th day of incubation. The decolorization of azo dyes such as Reactive Violet 13 and Reactive Blue 
171 at 50 and 100 ppm by Pseudomonas stutzeri in different media was studied by Gangavarapu and Ravuri [27]. According to the results, the maximum removal rates of Reactive Violet 13 and Reactive Blue 171 dyes (50 ppm) in Mineral Salt Media (MSM) were detected as 64\% and $66 \%$, whereas, $82 \%$ and $88 \%$ were measured as the highest decolorization values for the same dyes in Luria Broth (LB) media within $24 \mathrm{~h}$, respectively. Moreover, the usability of Bacillus cereus RJVL 2514 for the decolorization of Reactive Violet 13 and Reactive Blue 171 dyes were investigated by the same researchers in another work. It was reported that the highest dye removal percents were detected for Reactive Violet 13 and Reactive Blue 171 at $50 \mathrm{ppm}$ concentrations in MSM $(92 \%, 91 \%)$ and also LB media $(98 \%, 96 \%)$ within $24 \mathrm{~h}$, respectively [28].

Table 1: Decolorization rates of RB 171 by A1, D1, and D3 after different incubation periods

\begin{tabular}{ccccccc}
\hline Time & \multicolumn{6}{c}{ Dye Decolorization (\%) } \\
\cline { 2 - 7 } (h) & \multicolumn{2}{c}{ A1 } & \multicolumn{2}{c}{ D1 } \\
\cline { 2 - 7 } & Static & Agitated & Static & Agitated & Static & Agitated \\
\hline $\mathbf{2 4}$ & 68 & 14 & 23 & 77 & 22 & 78 \\
$\mathbf{4 8}$ & 81 & 26 & 49 & 88 & 41 & 88 \\
$\mathbf{7 2}$ & 84 & 30 & 83 & 88 & 75 & 89 \\
\hline
\end{tabular}

\subsection{Fungal dye decolorization}

P. ostreatus effectively decolorized the color of RB 171 in both static and agitated conditions at all incubation times tested (Fig. 4).

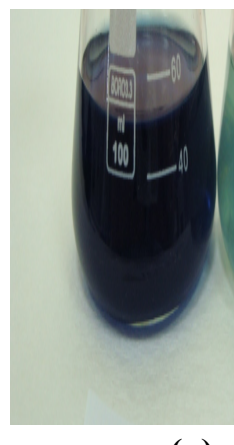

(a)

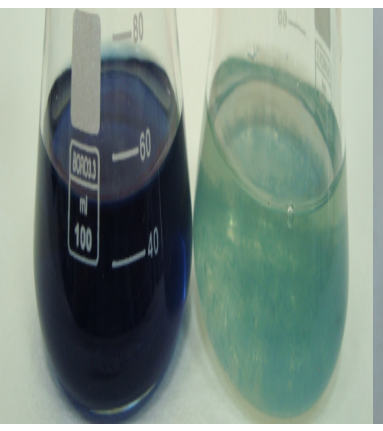

(b)

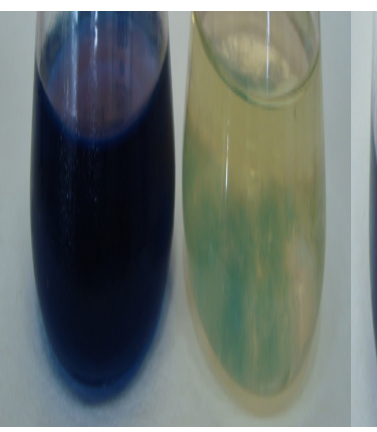

(c)

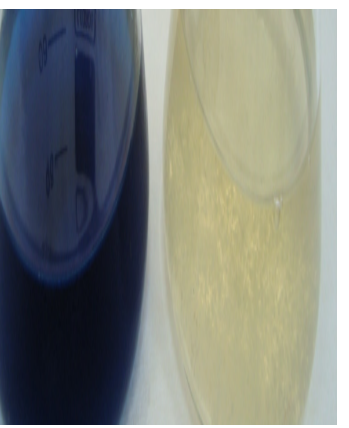

(d)

Figure 4: Macroscopic images of the decolorization of RB 171 by $P$. ostreatus under static conditions (a and $\mathrm{c}$ ) and agitated conditions ( $\mathrm{b}$ and d) after $3 \mathrm{~h}(\mathrm{a}$ and b) and $24 \mathrm{~h}(\mathrm{c}$ and d) incubation periods

Similarly, these color removals were also supported by spectrophotometric scanning (Fig. 5), and the percentages of the decolorization based on the time dependent absorbance measurements were showed at Table 2. The maximal color removal data were measured at 24th 
hour as $93 \%$ for static and also agitated conditions. Vantamuri and Kaliwal tested the white rot fungus Marasmius sp. BBKAV79 for decolorization and degradation of Navy Blue HER (Reactive Blue 171) dye at $50 \mathrm{mg} / \mathrm{L}$ within $24 \mathrm{~h}$ under agitated condition. It was reported that the dye decolorization rate was $91.25 \%$ at $50 \mathrm{mg} / \mathrm{L}$, but the decolorization value decreased to $37.50 \%$ at $150 \mathrm{mg} / \mathrm{L}$ [29]. In another work, Reactive Blue 171 dye removal rates were only $40 \%$ and $20 \%$ at 150 and $200 \mathrm{mg} / \mathrm{L}$ after the treatment with Trichosporon beigelii NCIM-3326 for 48 $\mathrm{h}$ under the static condition [30].

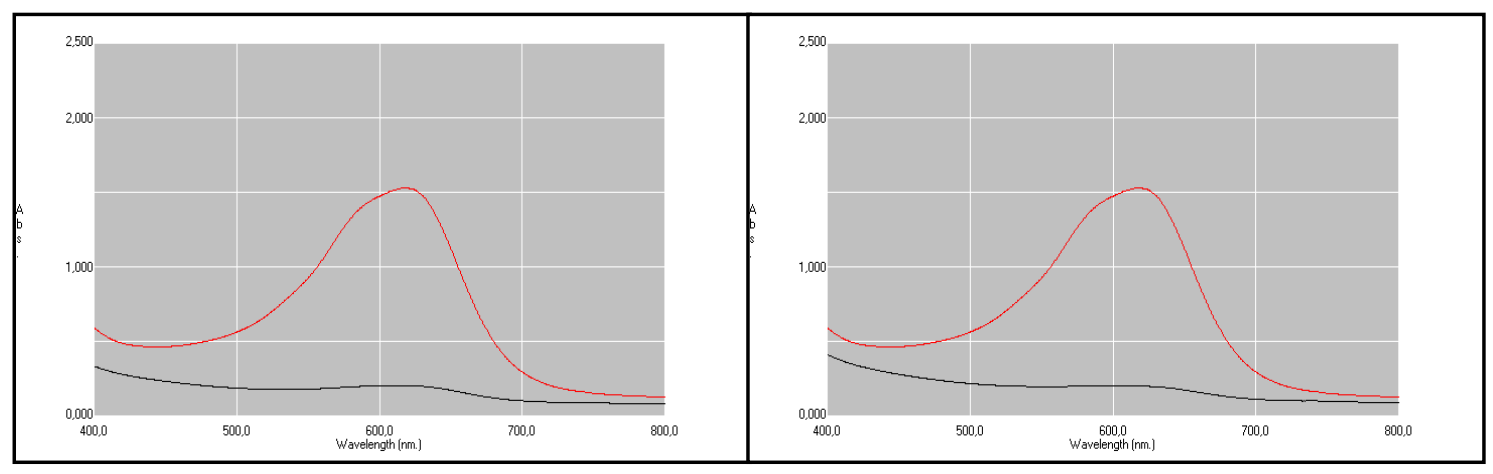

(a)

(b)

Figure 5: Spectrophotometric scanning images of the decolorization of RB 171 by $P$. ostreatus under static (a) and agitated conditions (b) after $3 \mathrm{~h}$ incubation period

Table 2: Decolorization rates of RB 171 by $P$. ostreatus after different incubation periods

\begin{tabular}{ccc}
\hline Time (h) & \multicolumn{3}{c}{ Dye Decolorization (\%) } \\
\cline { 2 - 4 } & Static & Agitated \\
\hline $\mathbf{3}$ & 87 & 87 \\
$\mathbf{6}$ & 89 & 90 \\
$\mathbf{9}$ & 91 & 91 \\
$\mathbf{1 2}$ & 91 & 92 \\
$\mathbf{2 4}$ & 93 & 93 \\
\hline
\end{tabular}

\subsection{Determination of Pleurotus ostreatus laccases by spectrophotometric analyzes}

Some researchers were reported that laccase production was induced when fungi incubated in the media containing dye [31-33]. Similarly, in this study, the results of spectrophotometric measurements showed that the laccase activity in SBM+150 mg/L RB 171 was higher (ten-fold) than the enzyme activity in SBM. The increase of laccase activity in dyecontaining SBM compared to SBM can be seen macroscopically in Fig. 6. 


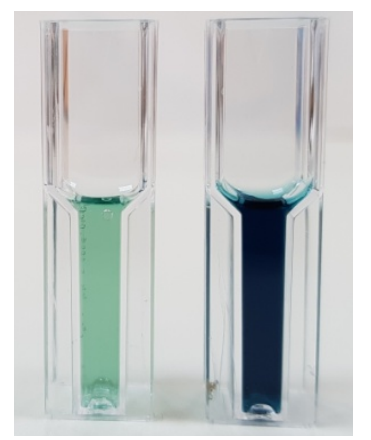

(a)

(b)

Figure 6: Spectrophotometric images resulting from the reaction of Pleurotus ostreatus culture fluids obtained from SBM (a) and SBM+150 mg/L RB 171 (b) with ABTS for 1 minute

\subsection{Determination of Pleurotus ostreatus laccases by zymogram analysis}

According to the zymogram analysis, one laccase band was observed in Pleurotus ostreatus culture liquid obtained from SBM while two laccase bands were observed in the fungal culture fluid from SBM containing $150 \mathrm{mg} / \mathrm{L}$ RB171 (Fig. 7). As mentioned above, higher laccase production in the dye-containing medium is also seen in the zymogram analysis. Accordingly, more intense laccase bands were detected in the culture fluid obtained from the dye-containing SBM compared to the culture fluid from SBM. This suggests that the dye tested (RB 171) induces the laccase production of Pleurotus ostreatus.

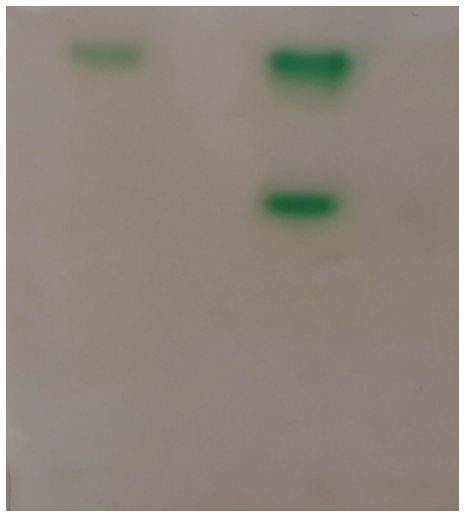

(a)

(b)

Figure 7: Zymogram of the crude laccases produced by incubation of Pleurotus ostreatus in SBM (a) and $\mathrm{SBM}+150 \mathrm{mg} / \mathrm{L} \mathrm{RB} 171$ (b)

\section{Conclusion}

This study performed by using three bacteria and a white rot fungus had shown that the color of RB 171 textile dye could be effectively removed in a short time and economically under static and agitated conditions. Furthermore, the spectrophotometric and zymogram analyzes showed that the laccase enzyme produced by Pleurotus ostreatus could play a role in 
the decolorization process, and also the dye tested could also induce the laccase production. According to the data obtained from this study, an economical and rapid solution to environmental pollution can be found by removing the color of many textile dyes completely or at a high rate with various microorganisms. In addition, the production of an industrial enzyme, laccase can be increased during the decolorization process.

\section{Acknowledgement}

We would like to thank the Inonu University Research Fund Unit for their financial support (2013/66) throughout this study.

\section{References}

[1] Karim, M.E., Dhar, K., Hossain, M.T., Decolorization of textile reactive dyes by bacterial monoculture and consortium screened from textile dyeing effluent, Journal of Genetic Engineering and Biotechnology, 16 (2), 375-380, 2018.

[2] Robinson, T., Chandran, B., Nigam, P., Removal of dyes from an artificial textile dye effluent by two agricultural waste residues, corncob and barley husk, Environment International, 28 (1-2), 29-33, 2002.

[3] Elshafei, A.M., Elsayed, M.A., Hassan, M.M., Haroun, B.M., Othman, A.M., Farrag, A.A., Biodecolorization of six synthetic dyes by Pleurotus ostreatus ARC280 laccase in presence and absence of hydroxybenzotriazole (HBT), Annual Research and Review in Biology, 15, 1-16, 2017.

[4] Hu, T.L., Wu, S.C., Assessment of the effect of azo dye $R P_{2} B$ on the growth of a nitrogen fixing cyanobacterium-Anabaena sp., Bioresource Technology, 77 (1), 93-95, 2001.

[5] Dogan, E.E., Yesilada, E., Ozata, L., Yologlu, S., Genotoxicity testing of four textile dyes in two crosses of Drosophila using wing somatic mutation and recombination test, Drug and Chemical Toxicology, 28 (3), 289-301, 2005.

[6] Saratale, R.G., Saratale, G.D., Chang, J.S., Govindwar, S.P., Bacterial decolorization and degradation of azo dyes: A review, Journal of the Taiwan Institute of Chemical Engineers, 42 (1), 138-157, 2011.

[7] Banat, I.M., Nigam, P., Singh, D., Marchant, R., Microbial decolorization of textiledye-containing effluents: A review, Bioresource Technology, 58 (3), 217-227, 1996.

[8] Yesilada, O., Birhanli, E., Ozmen, N., Ercan, S., Highly stable laccase from repeatedbatch culture of Funalia trogii ATCC 200800, Applied Biochemistry and Microbiology, 50 (1), 55-61, 2014.

[9] Meerbergen, K., Willems, K.A., Dewil, R., Impe, J.V., Appels, L., Lievens, B., Isolation and screening of bacterial isolates from wastewater treatment plants to decolorize azo dyes, Journal of Bioscience and Bioengineering, 125 (4), 448-456, 2018. 
[10] Singh, R.P., Singh, P.K., Singh, R.L., Bacterial decolorization of textile azo dye acid orange by Staphylococcus hominis RMLRT03, Toxicology International, 21 (2), 160-166, 2014.

[11] Parmar, N., Shukla, S.R., Microbial decolorization of reactive dye solutions, CleanSoil Air Water, 43 (10), 1426-1432, 2015.

[12] Yeşilada, Ö., Birhanl1, E., Ercan, S., Özmen, N., Reactive dye decolorization activity of crude laccase enzyme from repeated-batch culture of Funalia trogii. Turkish Journal of Biology, 38 (1), 103-110, 2014.

[13] Boran, F., Birhanl1, E., Yeşilada, Ö., Özbey, E., Comparison of indigo carmine decolorization by Pseudomonas aeruginosa and crude laccase enzyme from Funalia trogii, Turkish Journal of Biology, 43 (1), 37-46, 2019.

[14] Akpinar, M., Urek, R.O., Induction of fungal laccase production under solid state bioprocessing of new agroindustrial waste and its application on dye decolorization, 3 Biotech, 7 (2), 1-10, 2017.

[15] Jasińska, A., Góralczyk-Bińkowska, A., Soboń, A., Długoński J., Lignocellulose resources for the Myrothecium roridum laccase production and their integrated application for dyes removal. International Journal of Environmental Science and Technology, 16, 4811-4822, 2019.

[16] Liu, J., Sun, S., Han, Y., Meng, J., Chen, Y., Yu, H., Zhang, X., Ma, F., Lignin waste as co-substrate on decolorization of azo dyes by Ganoderma lucidum, Journal of the Taiwan Institute of Chemical Engineers, 122, 85-92, 2021.

[17] Kahraman, S., Kuru, F., Dogan, D., Yesilada, O., Removal of indigo carmine from an aqueous solution by fungus Pleurotus ostreatus, Archives of Environmental Protection, 38 (3), 51-57, 2012.

[18] Yesilada, O., Yildirim, S.C., Birhanli, E., Apohan. E., Asma, D., Kuru, F., The evaluation of pre-grown mycelial pellets in decolorization of textile dyes during repeated batch process, World Journal of Microbiology and Biotechnology, 26 (1), 33-39, 2010.

[19] Ulu, A., Birhanli, E., Boran, F., Köytepe, S., Yesilada, O., Ateş, B., Laccaseconjugated thiolated chitosan-Fe3O4 hybrid composite for biocatalytic degradation of organic dyes, International Journal of Biological Macromolecules, 150, 871-884, 2020.

[20] Tripathi, A., Srivastava, S.K., Ecofriendly treatment of azo dyes: biodecolorization using bacterial strains, International Journal of Bioscience, Biochemistry and Bioinformatics, 1(1), 37-40, 2011.

[21] Sneha, U., Poornima, R., Sridhar, S., Decolorization of synthetic textile dyes using Pseudomonas putida, Journal of Chemical and Pharmaceutical Research, 5(5), 219-225, 2013.

[22] Singh, R.P., Singh, P.K., Singh, R.L., Bacterial decolorization of textile azo dye acid orange by Staphylococcus hominis RMLRT03, Toxicology International, 21(2), 160-166, 2014. 
[23] Li, G., Peng, L., Ding, Z., Liu, Y, Gu, Z., Zhang, L., Shi, G., Decolorization and biodegradation of triphenylmethane dyes by a novel Rhodococcus qingshengii JB301 isolated from sawdust, Annals of Microbiology, 64, 1575-1586, 2014.

[24] Ganapathy, B., Chanderan, I., Ponnaiah, P., Decolorizing palm oil mill effluent (pome) using plant polysaccharide degrading microorganisms isolated from soil, Polish Journal of Environmental Studies, 27 (2), 629-636, 2018.

[25] Barathi, S., Aruljothi, K.N., Karthik, C., Padikasan, I.A., Optimization for enhanced ecofriendly decolorization and detoxification of reactive blue 160 textile dye by Bacillus subtilis, Biotechnology Reports 28, e00522, 1-7, 2020.

[26] Chen, K.C., Wu, J.Y, Liou, D.J., Hwang, S.C.J., Decolorization of the textile dyes by newly isolated bacterial strains, Journal of Biotechnology, 101 (1), 57-68, 2003.

[27] Gangavarapu, V.L., Ravuri, J.M., Decolourization of reactive violet 13 and reactive blue 171 by Pseudomonas stutzeri RJVL 1514 isolated from dye contaminated soil, International Journal of Microbiology Research, 8 (5), 754-758, 2016.

[28] Gangavarapu, V.L., Ravuri, J.M., Decolourisation of reactive violet 13 and reactive blue 171 by Bacillus cereus RJVL 2514 isolated from dye contaminated soils, International Journal of Environmental Sciences, 7 (1), 30-39, 2016.

[29] Vantamuri, A.B., Kaliwal, B.B., Decolourization and biodegradation of navy blue her (reactive blue 171) dye from Marasmius sp. BBKAV79, 3 Biotech, 7 (1), 1-7, 2017.

[30] Saratale, R.G., Saratale, G.D., Chang, J.S., Govindwar, S.P., Decolorization and biodegradation of textile dye navy blue her by Trichosporon beigelii NCIM-3326, Journal of Hazardous Materials, 166 (2-3), 1421-1428, 2009.

[31] D’Souza, D.T., Tiwari, R., Sah., A.K, Raghukumar, C., Enhanced production of laccase by a marine fungus during treatment of colored effluents and synthetic dyes, Enzyme and Microbial Technology, 38, 504-511, 2006.

[32] Sánchez-López, M.I., Vanhulle, S.F., Mertens, V., Guerra, G., Figueroa, S.H., Decock, C., Corbisier, A.M., Penninckx, M.J., Autochthonous white rot fungi from the tropical forest: potential of Cuban strains for dyes and textile industrial effluents decolourisation. African Journal of Biotechnology, 7 (12), 1983-1990, 2008.

[33] Sing, N.N., Husaini, A., Zulkharnain, A., Roslan, H.A., Decolourisation capabilities of ligninolytic enzymes produced by Marasmius cladophyllus UMAS MS8 on remazol brilliant blue R and other azo dyes, Biomed Research International, 2017, 1-8, 2017. 